\title{
Numerical Simulation of a 3D Seepage Field of an Asphaltic and Concrete Core Rockfill Dam in an Arid Area
}

\author{
Da-Hai Guo ${ }^{1},{ }^{1}$ Yun Sun, ${ }^{2}$ and Xin-Bao Gu ${ }^{3}{ }^{3}$ \\ ${ }^{1}$ The Nuer Hydro-Junction Projection and Construction Authority in Xinjiang Tarim River Basin, Xinjiang, China 848300 \\ ${ }^{2}$ School of Civil and Transportation Engineering, Ningbo University of Technology, Ningbo, Zhejiang, China 315211 \\ ${ }^{3}$ School of Civil Engineering, Nanyang Institute of Technology, Nanyang, Henan, China 473004 \\ Correspondence should be addressed to Xin-Bao Gu; 15823405952@163.com
}

Received 25 November 2021; Revised 19 December 2021; Accepted 9 February 2022; Published 7 March 2022

Academic Editor: Mingdong Wei

Copyright (c) 2022 Da-Hai Guo et al. This is an open access article distributed under the Creative Commons Attribution License, which permits unrestricted use, distribution, and reproduction in any medium, provided the original work is properly cited.

This investigation focused on the three-dimensional (3D) seepage field simulation of an asphaltic concrete core rockfill dam (ACRD) under the design water level conditions. At first, the finite element theory of seepage is introduced in the arid area; then, a hydro-junction projection on the Nuer River in Xinjiang is selected as engineering background, the finite element model of a seepage field of an asphaltic and concrete core rockfill dam under the design water level condition is established, and a boundary condition is determined, and the next distribution of a seepage field of different profiles are plotted, and the monitoring value of different points is compared with the finite element solution; conclusions can be drawn that when the antiseepage system of the dam foundation is good, the water level at the downstream side of the core wall is greatly reduced; for the dam foundation, the effects of reducing head of the cutoff wall are rather obvious, and for the dam body, certain leakage defects at the joint of an impermeable body in the cross sections $0+456.5 \mathrm{~m}$ and $0+540 \mathrm{~m}$ can exist. For the damaround seepage, the hydrogeological condition conforms to the actual conditions. These conclusions can provide great significance for the future design.

\section{Introduction}

A dam is a water storage construction, and it has many types [1], for example, an embankment dam and a concrete dam, but a core wall dam is applied widely in the world currently $[2,3]$, because it has many virtues, such as simple construction, good adaptability to dam foundation conditions, good seismic performance, and economy to invest in [4]. For the core wall dam, the distribution of a seepage field is an important issue for the safety of the dam [5].

To monitor the seepage distribution of the core wall dam, many researches have been performed by many researchers [6, 7]. Xu et al. [8] developed a threedimensional (3D) finite element procedure based on a modified generalized plasticity mode to simulate the construction process; a particle swarm optimization algorithm is introduced by Xiang et al. [9] during the modeling process; the lag effects of water level in osmometers are performed in the investigation. Then, a nonlinear elastic deformation and an unsteady seepage coupling model are suggested to simulate the seepage and deformation process by Chen and Zhang [10]; the Monte Carlo simulation and random field theory are applied to simulate the seepage of an embankment dam by Tan et al. [11]; the seepage behavior in the drainage area of a face sand is investigated by Choo et al. [12]; an inversion of dam seepage parameters based on the finite element model is performed by Ren et al. [13]. But these investigations intend to the wet area, for the distribution of a seepage field in the arid area; the investigation is scarce; the investigation area in the paper is located in Xinjiang Province, China. It is a typical arid area; there is no infiltration in the arid area $[14,15]$, so a simulation of a $3 \mathrm{D}$ seepage field in the arid area becomes an important issue in the paper.

The paper is organized as follows: in Section 2, the finite element method of seepage is introduced at first; in Section 3 , the numerical model of specific engineering example is established, and boundary conditions are determined; in 
Section 4 results and discussion are investigated; in Section 5 , conclusions are drawn.

\section{The Finite Element Method of Seepage}

The permeable mediums including fractured rock mass are regarded as continuous anisotropic mediums in the paper. It is assumed in rock hydraulics for the fractured rock, if fissures are more developed, and representative elementary volume exists, its magnitude is not big enough, and it can be regarded as the groundwater movement $[16,17]$ and confirms to saturated and stable Darcy seepage law of incompressible flow. They can be expressed as follows:

$$
v_{i}=-k_{i j} J_{j}=-k_{i j} h_{j}, \quad(i, j=1,2,3),
$$

where $v_{i}$ is the velocity component, $k_{i j}$ is the infiltrate tensor,

$\vec{J}$ is the hydraulic gradient, and $h$ is the water head.

When Equation (1) is substituted into the continual equation of seepage $v_{i, i}=0$, it can be expressed as follows [18-20]:

$$
\left(k_{i j} h_{j}\right)_{i}=w, \quad(i, j=1,2,3),
$$

where $w$ is the steady rainfall infiltration and evaporation capacity.

Its mixed boundary can be expressed as follows:

$$
h(x, y, z)+\alpha \frac{\partial h(x, y, z)}{\partial n}=\beta, \quad(x, y, z) \in \Gamma_{3},
$$

where $\alpha, \beta$ is the constant.

According to Snow's theory, it is assumed that the fissures in the rock mass are generalized as the $N$ groups; the unit normal vector of fissures in the $k$-th groups is $\vec{n}^{(k)}$; the average opening degree is $b_{k}$; when different groups of fissures are all infinite extensive [21], it can be expressed as follows:

$$
k_{i j}=\sum_{k=1}^{N} \frac{\rho_{k} g \bar{b}_{k}^{3}}{12 \mu}\left(\delta_{i j}-n_{i}^{(k)} n_{j}^{(k)}\right)
$$

where $\rho_{k}$ is the mean bulk density and $\bar{b}_{k}$ is the average equivalent hydraulic gap width; namely, $\bar{b}_{k}^{3}=\sum_{s=1}^{m}\left(b_{k}^{(s)}\right)^{3}$ / $m_{(k)}$, where $m_{(k)}$ is the total number of the $k$-th group of fissures and $b_{k}^{(s)}$ is the equivalent hydraulic gap width in the $s^{\text {th }}$ fissure; to consider nonthrough fracture, the fissures are assumed as the circle, and its mean radius is $r_{(k)}$; infiltration tensor can be obtained as follows according to Equation (5):

$$
k_{i j}=\sum_{k=1}^{N} \frac{g}{v} \pi r_{(k)}^{2} \lambda_{(k)} \rho_{(k)} b_{(k)}^{3}\left(\delta_{i j}-n_{(k) i} n_{(k) j}\right),
$$

where $g$ is the gravity acceleration, $v$ is the coefficient of kinematic viscosity, $r$ is the radius of slit disk, $\lambda$ is a dimensionless coefficient that reflected the fracture con- nectivity and number of intersections among different groups of fissures, $0 \leq \lambda \leq 1 / 12$, when the fissures are nonthrough, $\lambda=1 / 12 ; \rho$ is the volume density in the $k$-th group of fissures, $\rho=m_{(k)} / V$.

According to Equation (2), the basic equation of threedimensional seepage of the finite element can be shown as follows:

$$
[M]^{e} p^{e}=F^{e}
$$

where $p^{e}$ is the water pressure of element and $[M]^{e}$ is the seepage matrix of element; they can be shown as follows:

$$
m_{i j}=\int_{\Omega^{e}} N_{i, l} K_{l m} N_{j, m} d \Omega, \quad(i, j=1, \cdots, 8 ; \quad l, m=1,2,3),
$$

$$
F_{j}=-\int_{\Omega^{e}}\left(\frac{\partial N_{j}}{\partial x} k_{x z}+\frac{\partial N_{j}}{\partial y} k_{y z}+\frac{\partial N_{j}}{\partial z} k_{z z}\right) p d \Omega+\int_{S} N_{j} \bar{q} d s,
$$

where $N_{i}$ is the form function of isoperimetric element in eight nodes in space.

Finally, the whole filtration matrix can be formed from the element filtration matrix as follows [22]:

$$
[M] p=F
$$

Initial flow method is adopted to solve the matrix. According to the method, the Darcy law can be revised as follows:

$$
v_{i}=-k_{i j} h_{j}+q_{i}^{0}, \quad(i, j=1,2,3)
$$

where $v_{i}$ is the flow rate, $k_{i j}$ is the infiltrate sensor, and $q_{i}^{0}$ is the initial value of flow capacity.

There is no infiltration in the arid area; $v_{i}$ can be rewritten as follows:

$$
v_{i}=-k_{i j}^{0} h_{j}, \quad(i, j=1,2,3),
$$

where $k_{i j}^{0}= \begin{cases}k_{i j}, & \text { for wet area, } \\ 0, & \text { for arid area. }\end{cases}$

The value of initial flow can be shown as follows:

$$
q_{i}^{0}=\left(-k_{i j}^{0}+k_{i j}\right) h_{j}, \quad(i, j=1,2,3)
$$

Substituting Equation (12) into continual equation of seepage, it can be obtained as follows:

$$
\left(-k_{i j} h_{j}+q_{i}^{0}\right)_{i}=0, \quad(i, j=1,2,3)
$$

According to the Galerkin method, the whole region is discrete, and the finite element equation can be rewritten 


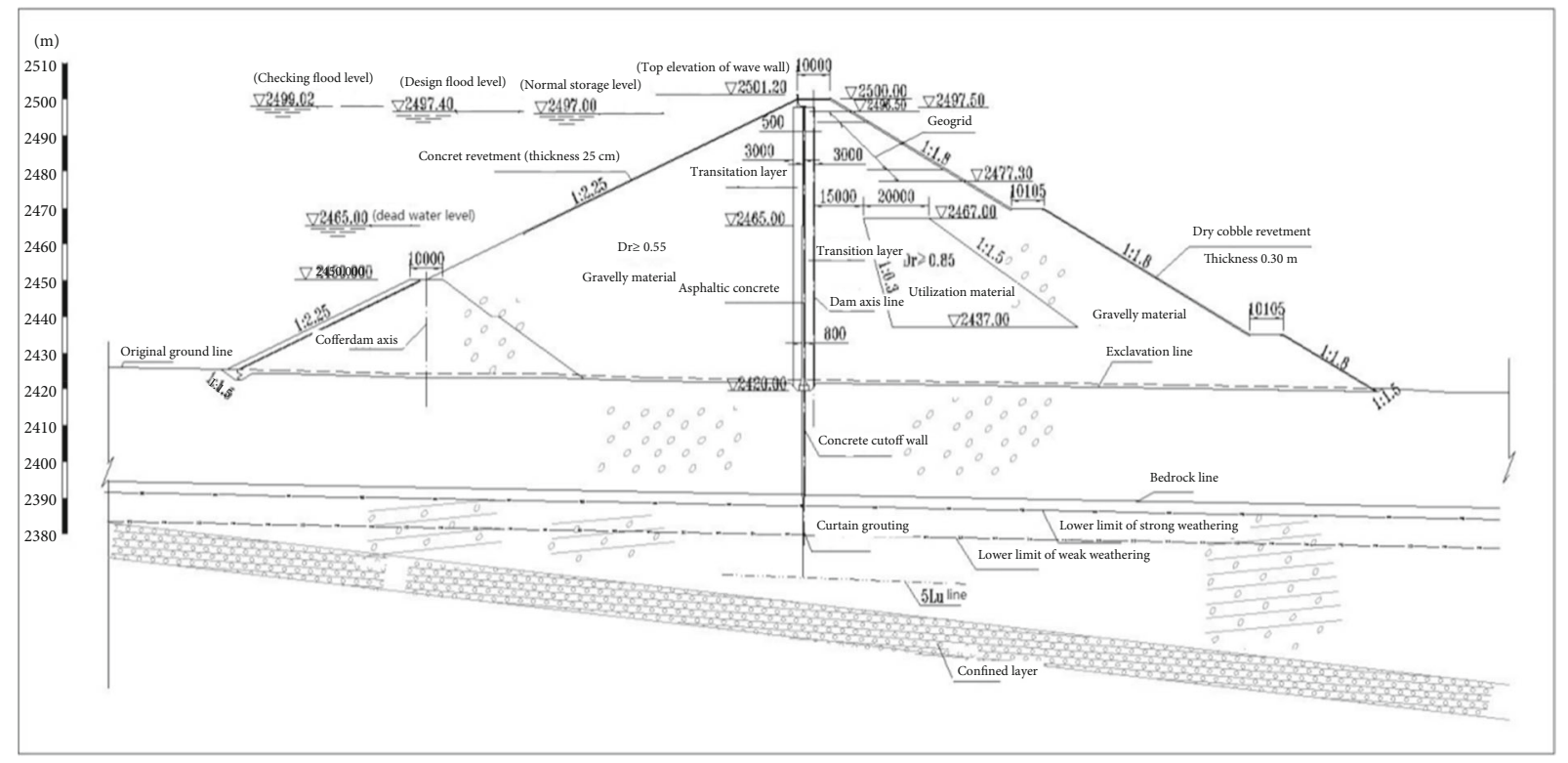

Figure 1: Typical profile of dam.

as follows $[23,24]$ :

$$
[M] \cdot h=Q+Q_{0}
$$

where $[M]$ and $Q$ are the separately global conduction matrix and equivalent node flow, respectively, $Q_{0}$ is the equivalent node flow derived from initial flow, and $Q_{0}$ can be expressed as follows [25]:

$$
Q_{0}=\sum_{e}\left(\sum_{i=1}^{8}\left[B\left(\xi_{i}, \eta_{i}, \varsigma_{i}\right)\right]^{\mathrm{T}}\left([k]-\left[k^{0}\right]\right)\left[B\left(\xi_{i}, \eta_{i}, \varsigma_{i}\right)\right]\left|J_{i}\right|\right) h^{e}
$$

where $[B]$ is the geometric matrix of element and $h^{e}$ is the water head array in the node of element.

\section{Engineering Application Example}

3.1. Project Overview. The hydropower project under consideration in this investigation is located on the Nuer River. It is a controlled hydro-junction projection. A water diversion power generation system is located on the left bank; spillway and diversion tunnel are located on the right bank. Total capacity of reservoir is 0.69 billion $\mathrm{m}^{3}$, and its normal water storage level is $2497 \mathrm{~m}$; the dead water level is $2465 \mathrm{~m}$; the total installed capacity of power station is $6.2 \mathrm{MW}$; the average annual generation over many years is 0.217 billion $\mathrm{kWh}$, and the basic information of the dam are shown in Figure 1.

The dam is located in the riverbed; it is an asphaltic concrete core rockfill dam with a maximum height of $80 \mathrm{~m}$. Eolian low liquid limit silt is covered on the upper part of the left bank slope, and its thickness is $30 \sim 53 \mathrm{~m}$; Pleistocene alluvial sand and gravel are covered on the lower part of Pleistocene alluvial gravel, and its thickness is approximately $5 \sim 6 \mathrm{~m}$; the upper limit of a weak weathering layer of con- glomerate in western region is covered with the foundation in the left bank core $(0+000 \sim 0+040$ m section $)$; the upper limit of a weak weathered layer is covered with the foundation in the left bank core $(0+040 \sim 0+162 \mathrm{~m}$ section); Pleistocene-Holocene alluvial sand and gravel are covered in the channel core $(0+162 \sim 0+540 \mathrm{~m}$ section $)$; the $\mathrm{Q}^{3 \mathrm{al}}$ alluvial sand and gravel are covered in the depth of $0 \sim 15 \mathrm{~m} ; \mathrm{Q}^{2 \mathrm{al}}$ alluvial sand and gravel are located in the depth of $15 \sim 20 \mathrm{~m}$; the western conglomerate is located beneath the depth of $20 \mathrm{~m}$. Eolian low liquid limit silt is covered on the right bank slope (elevation is greater than $2730 \mathrm{~m}$ ), and its thickness is $35 \sim 45 \mathrm{~m}$; terrace gravel is covered on the right bank (elevation is under $2730 \mathrm{~m}$ ). According to geological survey and engineering experience, the infiltration coefficients, allowable gradient of different rock layers, and damming material are shown in Table 1.

3.2. The Establishment of the Equivalent Finite Element Model. To establish the model, $750 \mathrm{~m}$ (along upstream and downstream $) \times 1120 \mathrm{~m}$ (along the axis of the dam) in dimensions are adopted as a calculative range. It is plotted in Figure 2.

Based on the corresponding data, a three-dimensional seepage model in the hydro-junction area is established in Figure 3. Isotropic finite element of hexahedral eight-node is adopted in the model, and transitional articulation of tetrahedron element is also selected in a certain local area. In total, 55877 elements and 56126 nodes are generated in the model. The top view of the model is plotted in Figure 4 .

16 typical profiles are selected to plot a two-dimensional profile of a seepage field; the profiles parallel to the axis of the dam are numbered as 1 6 (they are, respectively, located at downstream of the dam axis: $0+1 \mathrm{~m}, 0+40 \mathrm{~m}, 0+80 \mathrm{~m}$, $0+120 \mathrm{~m}, 0+170 \mathrm{~m}$, and $0+400 \mathrm{~m})$; the profiles vertical to the axis of the dam are numbered as $7 \sim 14$ (their pile numbers are, respectively, $0+9 \mathrm{~m}, 0+110 \mathrm{~m}, 0+290 \mathrm{~m}, 0+$ 
TABLE 1: The infiltration coefficient and allowable descent.

\begin{tabular}{|c|c|c|}
\hline Material type & Average permeability $(\mathrm{cm} / \mathrm{s})$ & Allowable descent \\
\hline Western conglomerate $\mathrm{Q}_{1}$ (under confined aquifer) & $6.6 \times 10^{-5}$ & \\
\hline Confined aquifer & $8.52 \times 10^{-3}$ & \\
\hline The bedrock of confined aquifer $\mathrm{Q}_{1}$ (above confined aquifer) & $1.13 \times 10^{-4}$ & \\
\hline \multicolumn{3}{|c|}{ Weakly weathered layer $\left(\mathrm{Q}_{1}\right)$} \\
\hline Left bank & $5.99 \times 10^{-5}$ & \\
\hline Partial rock layer 1 & $1.25 \times 10^{-3}$ & \\
\hline Right bank & $4.59 \times 10^{-5}$ & \\
\hline \multicolumn{3}{|c|}{ Fresh rock mass $\left(\mathrm{Q}_{1}\right)$} \\
\hline Left bank & $2.78 \times 10^{-5}$ & \\
\hline Right bank & $3.35 \times 10^{-5}$ & \\
\hline $\mathrm{Q}_{2}^{\mathrm{al}}$ & $1.1 \times 10^{-2}$ & 0.12 \\
\hline $\mathrm{Q}_{3}{ }^{\mathrm{al}}$ & $1.6 \times 10^{-2}$ & 0.10 \\
\hline $\mathrm{Q}_{4}{ }^{\mathrm{al}}$ & $4.4 \times 10^{-2}$ & 0.08 \\
\hline $\mathrm{Q}_{3}{ }^{\mathrm{eol}}$ & $2.9 \times 10^{-4}$ & 2.0 \\
\hline Dam body & $2.5 \times 10^{-1}$ & \\
\hline Curtain grouting & $1.0 \times 10^{-5}$ & \\
\hline Concrete cutoff wall & $1.0 \times 10^{-7}$ & \\
\hline Concrete base & $1.0 \times 10^{-7}$ & \\
\hline Asphaltic and concrete core wall & $1.0 \times 10^{-7}$ & \\
\hline Consolidation grouting & $1.0 \times 10^{-4}$ & \\
\hline Cofferdam & $2.5 \times 10^{-1}$ & \\
\hline Dam material & $2.5 \times 10^{-1}$ & \\
\hline
\end{tabular}

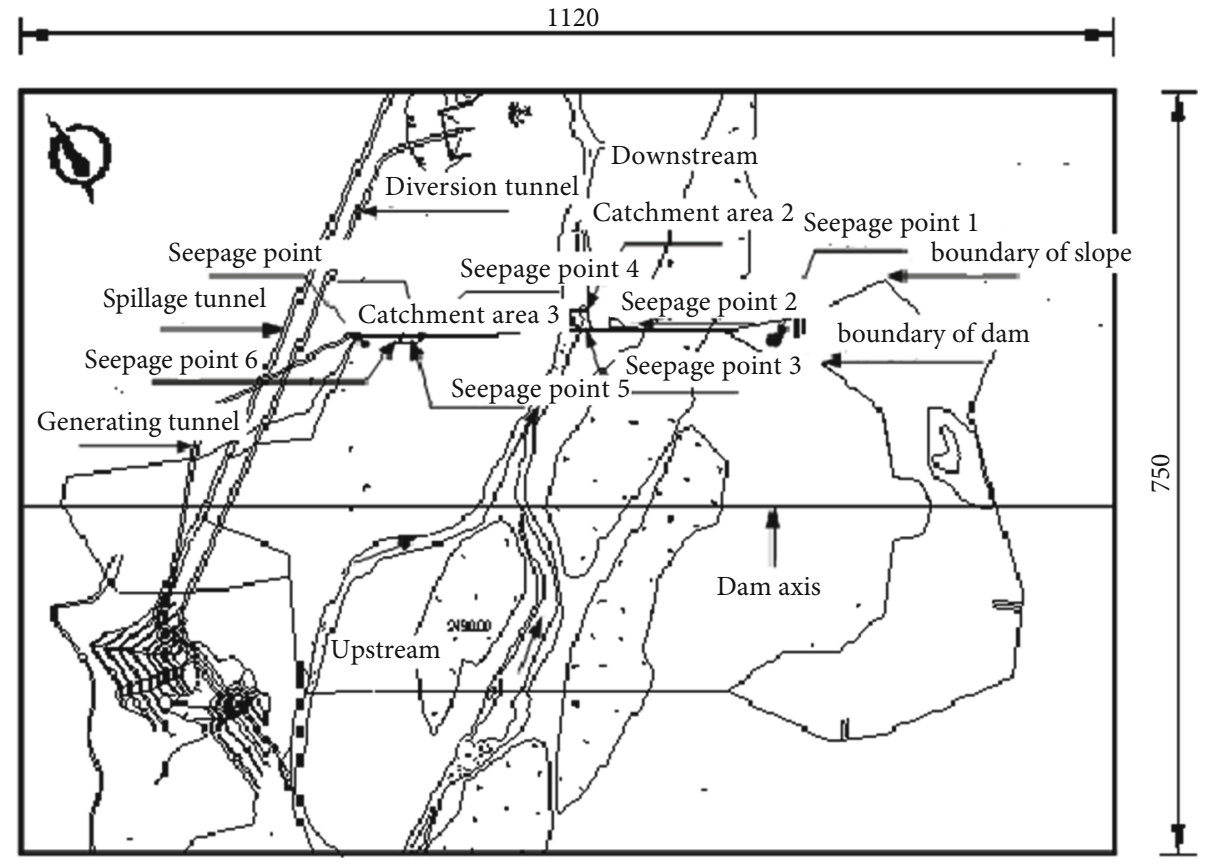

Figure 2: The range of calculative domain. 


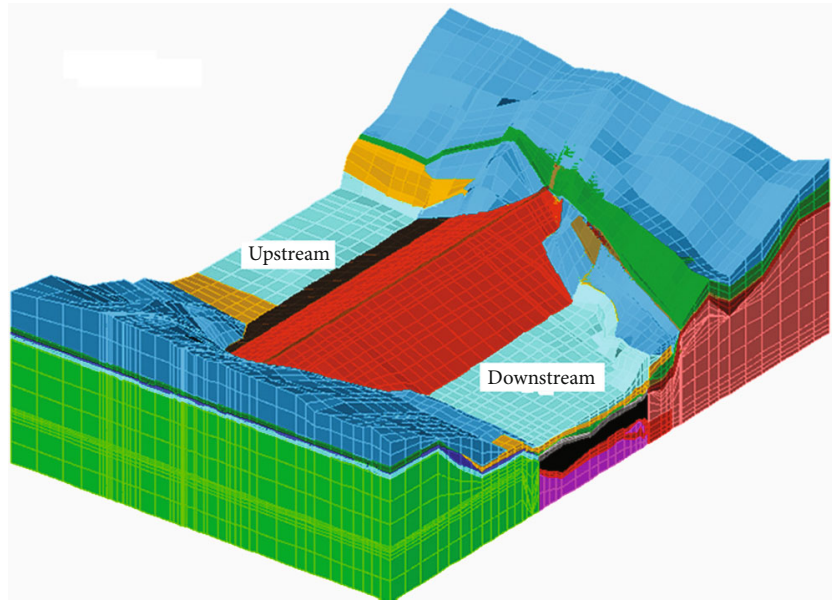

Figure 3: Three-dimensional finite element model of a hydrojunction area.

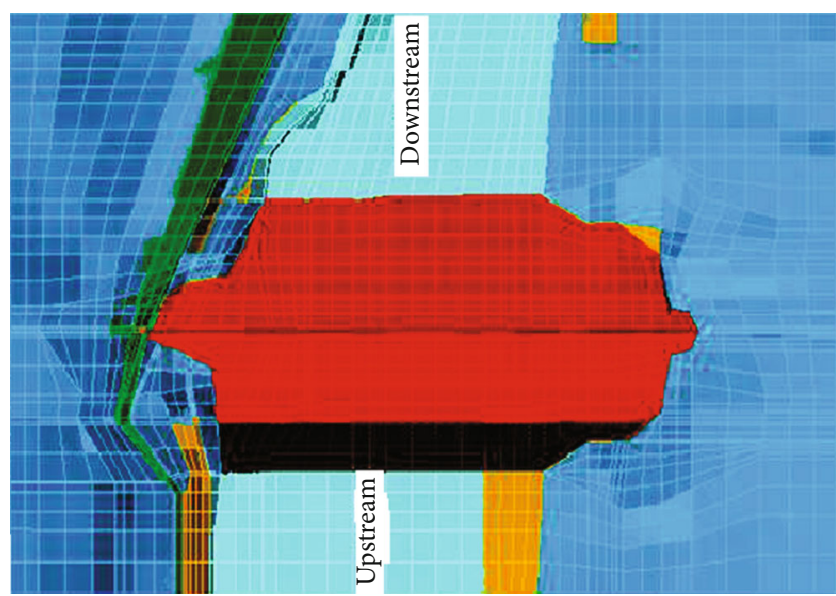

FIgURE 4: Top view of finite element model.

$373.5 \mathrm{~m}, 0+456.5 \mathrm{~m}, 0+540 \mathrm{~m}, 0+693 \mathrm{~m}$, and $0+735.62$ $\mathrm{m})$; the central axis profile of spillway is numbered as 15 ; the central axis profile of division tunnel is numbered as 16. The specific location of profiles is plotted in Figure 5.

3.3. The Determination of Boundary Condition. The schematic diagram of a boundary condition in the model is plotted in Figure 6. In the model, six boundary conditions are, respectively, set as follows:

(1) The cutoff boundary on the left and right banks and the upstream cutoff boundary and bottom boundary are, respectively, assumed as a water-proof boundary; a downstream cutoff boundary is defined as a water level of downstream riverbed

(2) The upper boundary condition: the place below water level of the reservoir at the upstream side is set as a given head boundary; the seepage boundary can exist at the place above the water level of the reservoir, so the upstream water level of reservoir is selected as $2470 \mathrm{~m}$; the place below the downstream water level at the downstream side is set as a given

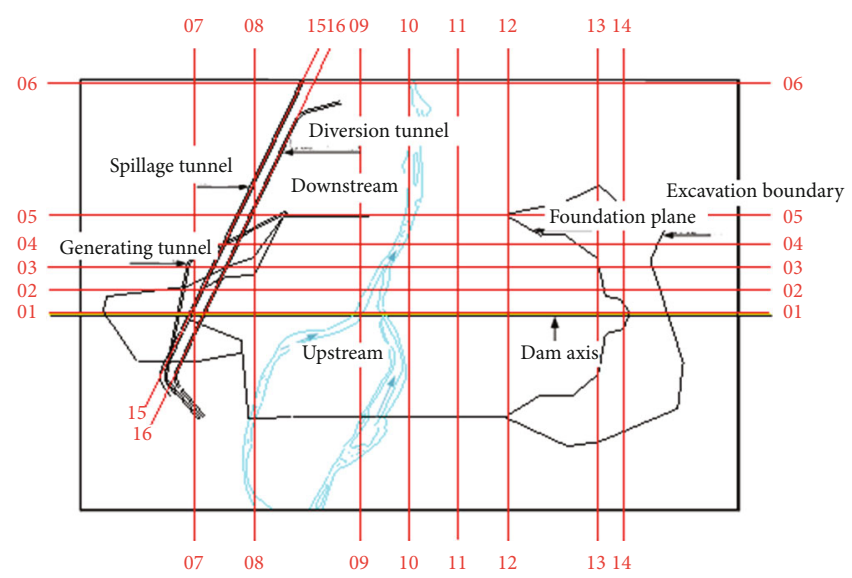

FIgURE 5: The position and number of a calculative area.

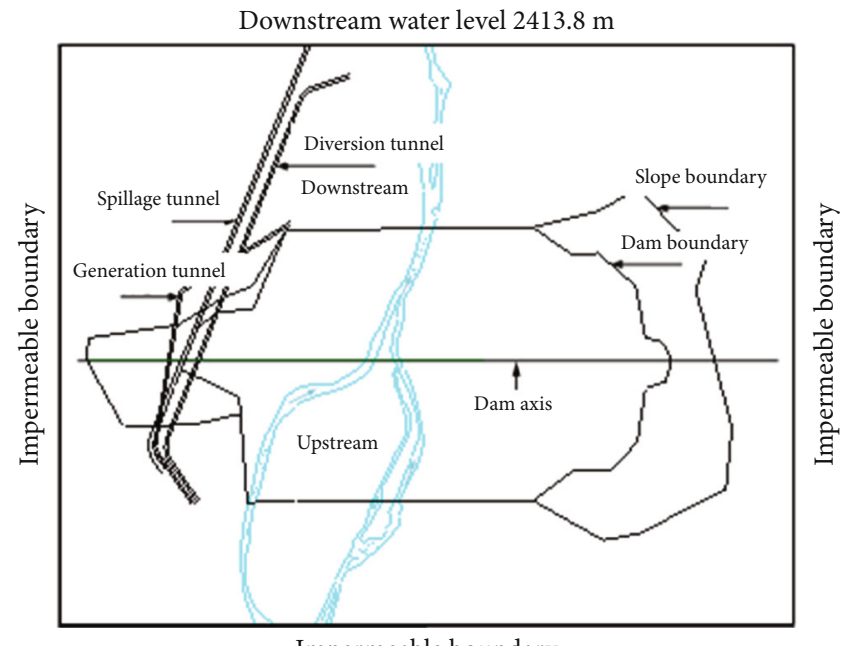

Impermeable boundary

FIgURE 6: The schematic diagram of a boundary condition.

head boundary; the seepage boundary can exist at the place above the downstream water level, so the water level of the downstream riverbed section is set as $2413.8 \mathrm{~m}$

\section{The Results and Discussion}

4.1. The Analysis of a Seepage Field under Design Water Level Conditions. The three-dimensional seepage field is analyzed when antiseepage system and the lining of hydraulic tunnel are both good. The isopotential maps of seepage filed at the typical profile of the dam are, respectively, plotted from Figures 7-16 as follows:

It can be found from Figure 7 to Figure 14 that when the antiseepage system of the dam foundation is good, the water level at the downstream side of the core wall in the dam body is greatly reduced, and the saturation line in the dam body is very low and smooth, and they are basically located in the overburden of the dam foundation; the distribution maps of the seepage field about the overflow and diversion tunnel are, respectively, plotted in Figures 15 and 16. It can be found in Figure 15 that for the spillage tunnel, the tunnel 


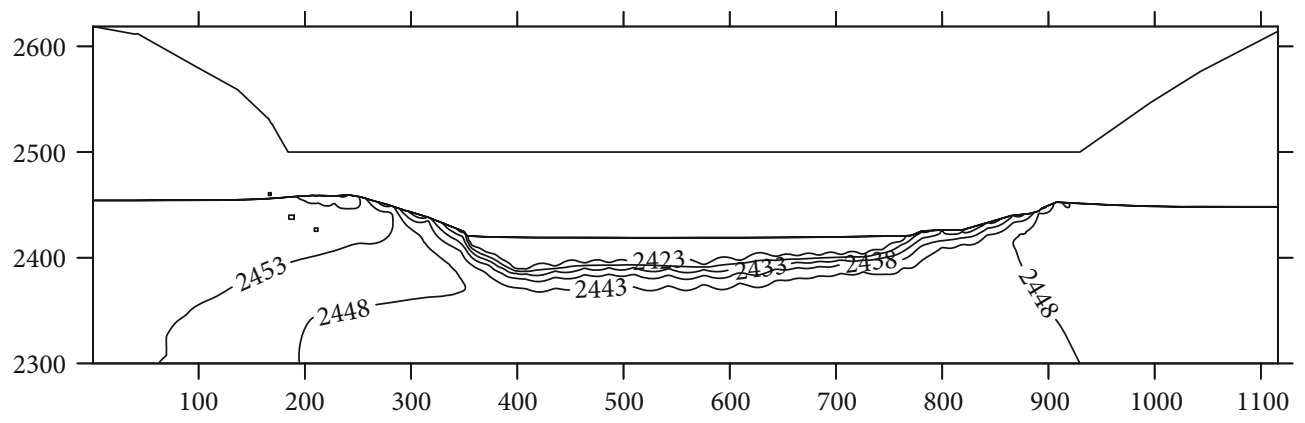

Figure 7: The isopotential distribution map of seepage field about dam foundation (1-1 profile).

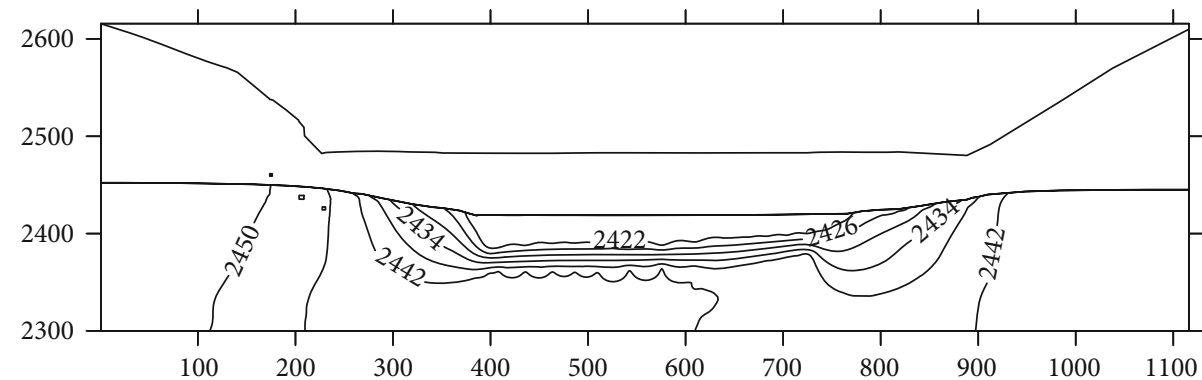

FIGURE 8: The isopotential distribution map of seepage field about dam foundation (2-2profile).

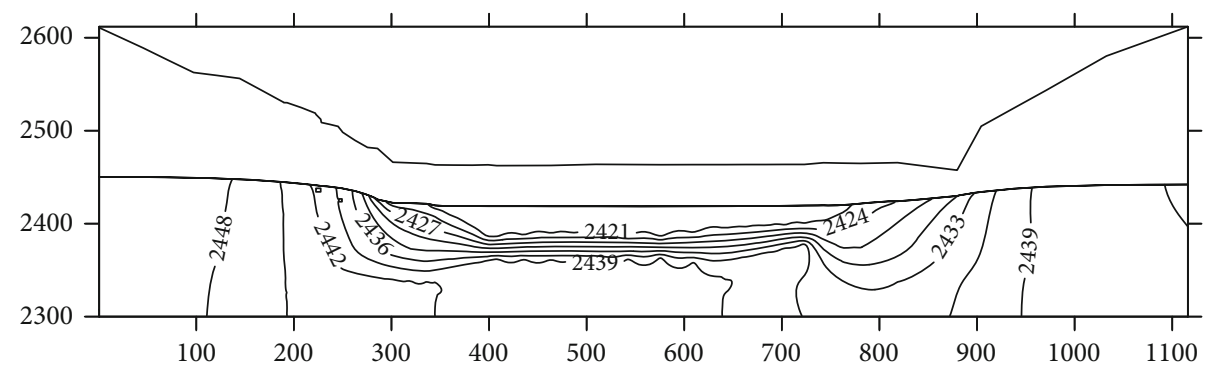

FIGURE 9: The isopotential distribution map of seepage field about dam foundation (3-3profile).

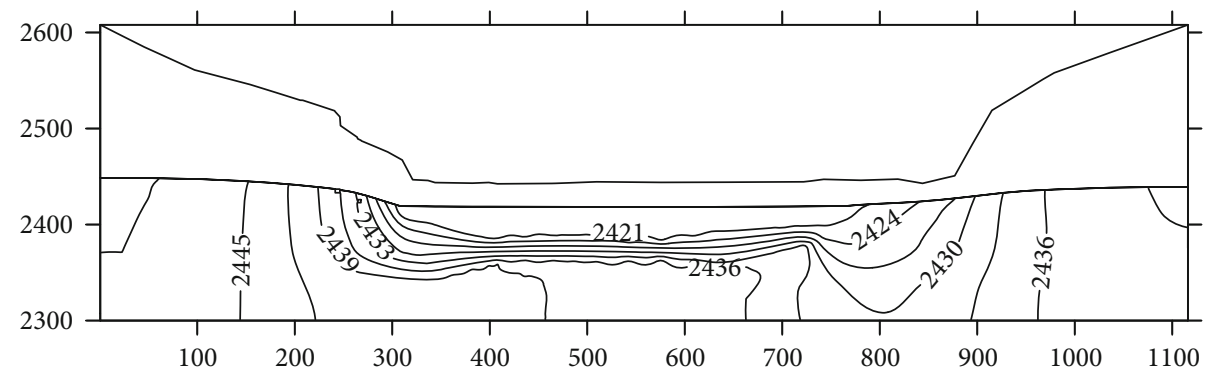

FIgUre 10: The isopotential distribution map of seepage field about dam foundation (4-4 profile).

body beyond pile number $0+300 \mathrm{~m}$ all is above the groundwater level; it can be found from Figure 16 that for the diversion tunnel, most of the tunnel body is under the groundwater level; the tunnel bodies beyond pile number 0 $+450 \mathrm{~m}$ all are near the groundwater level.

\subsection{The Analysis of Monitoring Point about the Seepage Field}

4.2.1. The Analysis of Monitoring Data about the Seepage of the Dam Foundation. Content of seepage monitoring in the hydro-junction projection is composed of three parts: seepage monitoring of the dam foundation, seepage monitoring of the dam body, and the dam-around seepage monitoring.

4.2.2. Seepage Monitoring of the Dam Foundation. The osmometers are buried in the dam foundation at the downstream of cross sections $0+290 \mathrm{~m}$ and $0+540 \mathrm{~m}$ in the cutoff wall. Their elevations are, respectively, $2406.5 \mathrm{~m}$ and $2407.5 \mathrm{~m}$.

\subsubsection{Seepage Monitoring of the Dam Body}




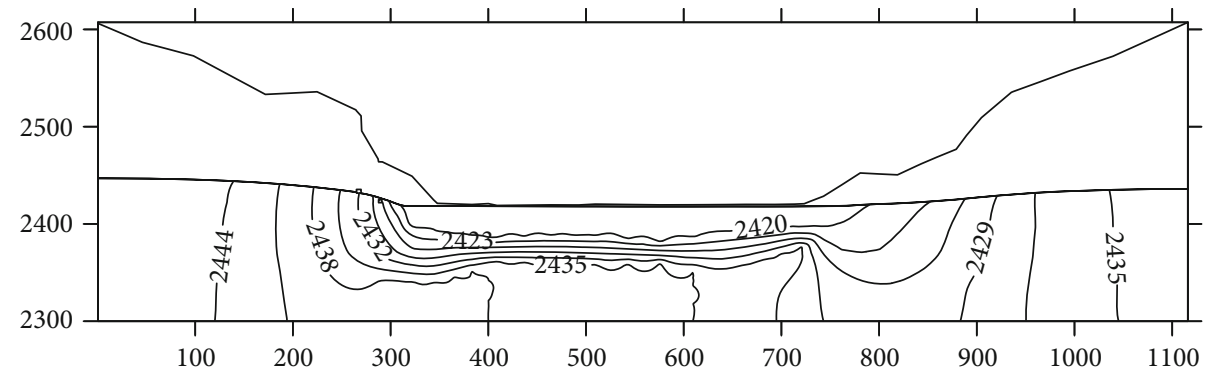

FIgURE 11: The isopotential distribution map of seepage field about dam foundation (5-5 profile).

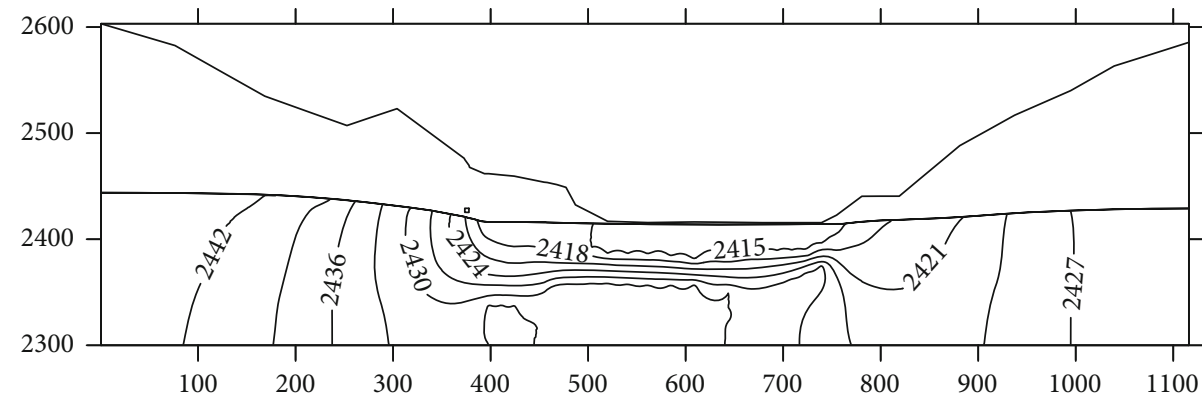

Figure 12: The isopotential distribution map of seepage field about dam foundation (6-6profile).

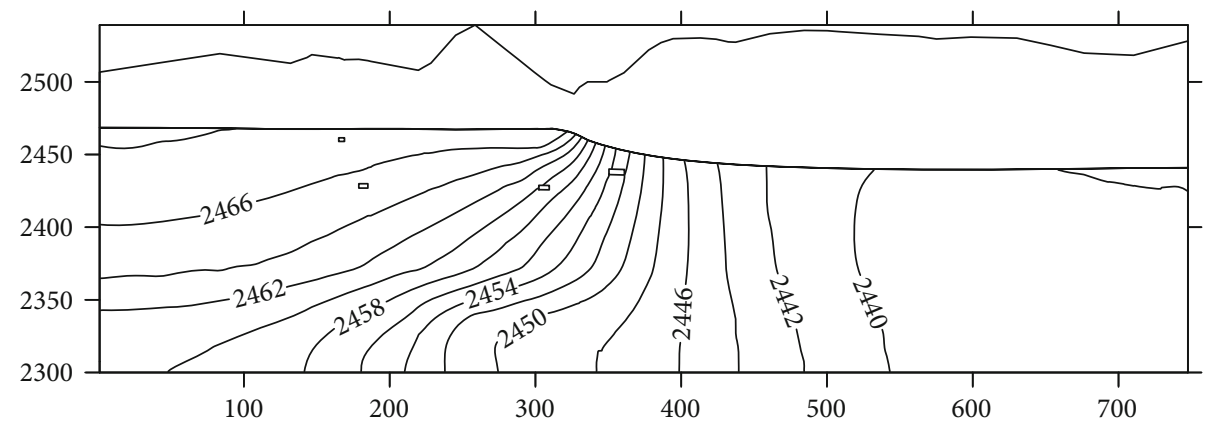

Figure 13: The isopotential distribution map of seepage field about dam foundation (7-7profile).

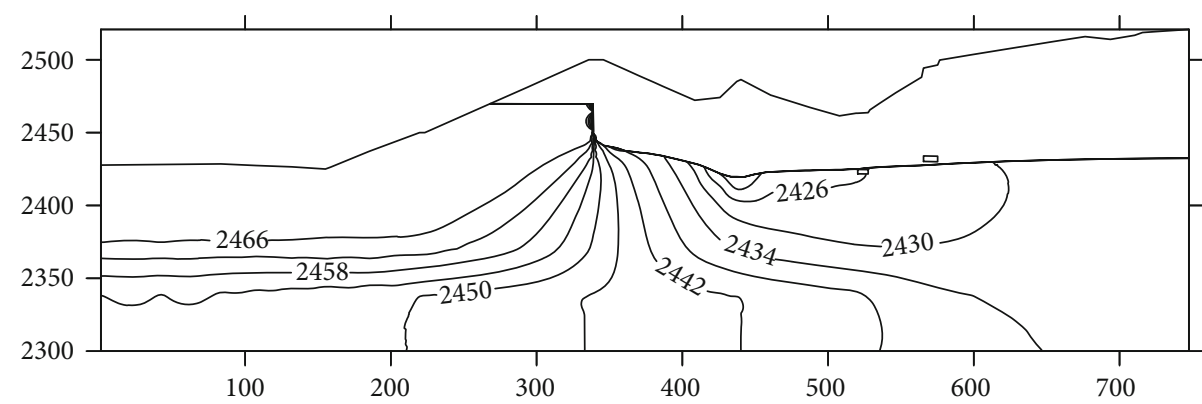

FIgUre 14: The isopotential distribution map of seepage field about dam foundation (8-8 profile).

(1) The Seepage Monitoring at the Downstream of Core Base. The osmometers that are buried in the downstream of core base are, respectively, numbered as P1, P10, P11, P3, P12, P13, P6, P14, P8, et al. The distribution map of water level about the seepage pressure of monitoring point along the dam axis is shown in Figure 17; it can be found in Figure 17 that the seepage pressure distribution curve of dif- ferent monitoring points is basically consistent with the one of a concrete core dam; however, the higher osmotic water level possibly exists in blue circle.

(2) The Seepage Monitoring of the Downstream Dam Body. The distribution maps of seepage pressure on the cross sections $0+290 \mathrm{~m}$ and $0+540 \mathrm{~m}$ are, respectively, plotted 


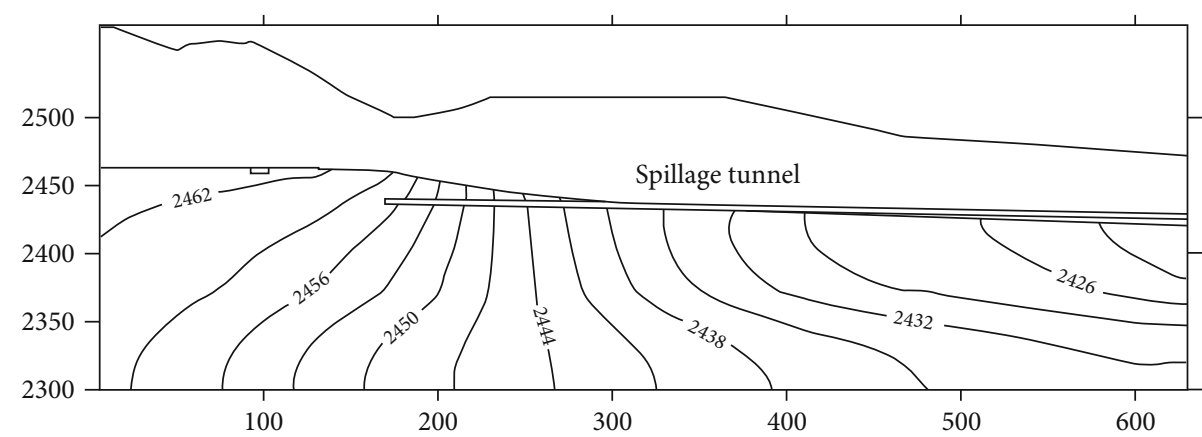

Figure 15: The isopotential distribution map of seepage field about dam foundation (15-15 profile).

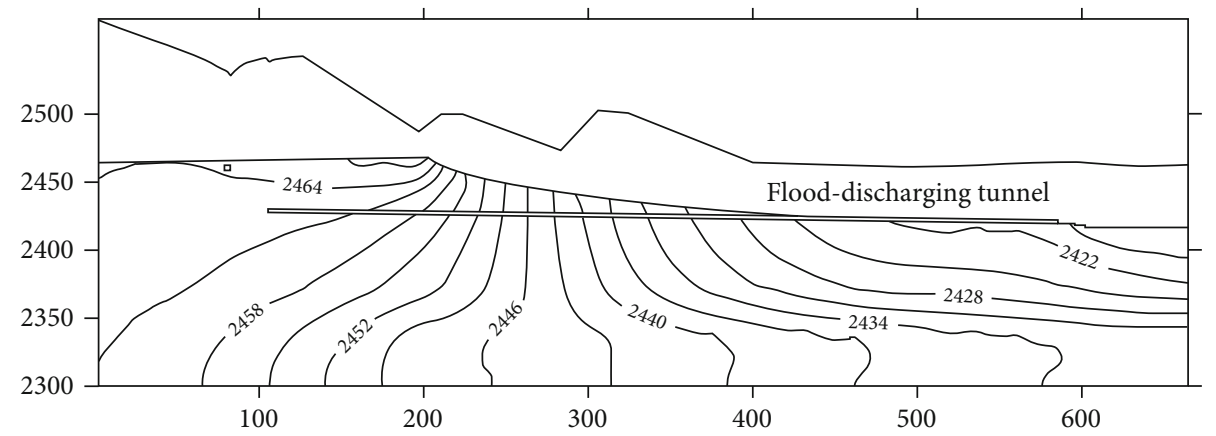

Figure 16: The isopotential distribution map of seepage field about dam foundation (16-16 profile).

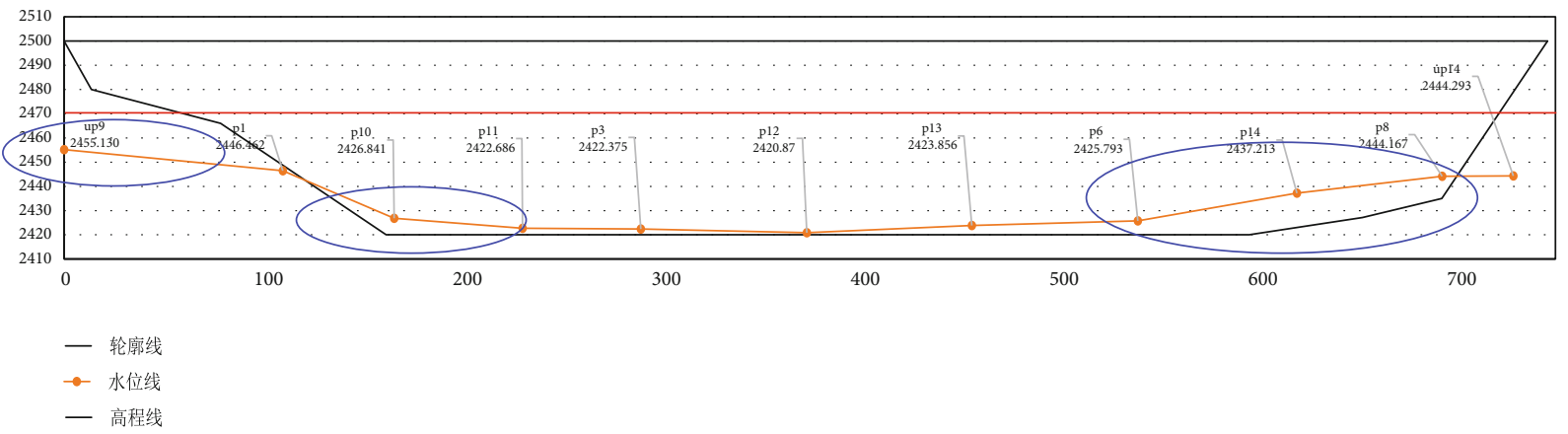

FigURE 17: Monitoring value of lateral osmotic pressure downstream.

in Figures 18 and 19. It can be found from Figures 18 to 19 that the seepage pressure distribution of different points basically conforms to seepage pressure distribution law. But the distribution of seepage pressure among monitoring points $\mathrm{P} 6$ and $\mathrm{P} 5, \mathrm{P} 3$, and $\mathrm{P} 2$ is abnormal; the phenomenon can be originated from the leakage defects of joint in the concrete base.

(3) Dam-Around Seepage Monitoring. The monitoring points UP9, UP10, and UP11 are, respectively, buried on the left bank at the distances $13 \mathrm{~m}, 21 \mathrm{~m}$, and $120 \mathrm{~m}$ from the downstream; the monitoring points UP14, UP13, and UP12 are, respectively, buried on the right bank at the distances $6 \mathrm{~m}, 83 \mathrm{~m}$, and $113 \mathrm{~m}$ from the downstream.

\subsection{The Comparative Analysis of Seepage Water Level}

4.3.1. Seepage Comparison of the Dam Foundation. The monitoring value of seepage pressure at the monitoring points P2 and P5 of the cross sections $0+290 \mathrm{~m}$ and 0 $+540 \mathrm{~m}$ along the downstream of cutoff wall is compared with the value of FEM simulation. It is shown in Table 2 that the values of FEM simulation are lower more than $1 \mathrm{~m}$ than monitoring value, and it also can be seen that the reduced head of monitoring points arrives at over $77.5 \%$ in both methods. The effects of reducing head of the cutoff wall are rather obvious. The whole of cutoff wall is in good case.

\subsubsection{Seepage Comparison of the Dam Body}

(1) The Seepage Monitoring at the Downstream of Core Base. The monitoring value of seepage pressure along the downstream of core base is compared with the value of FEM 


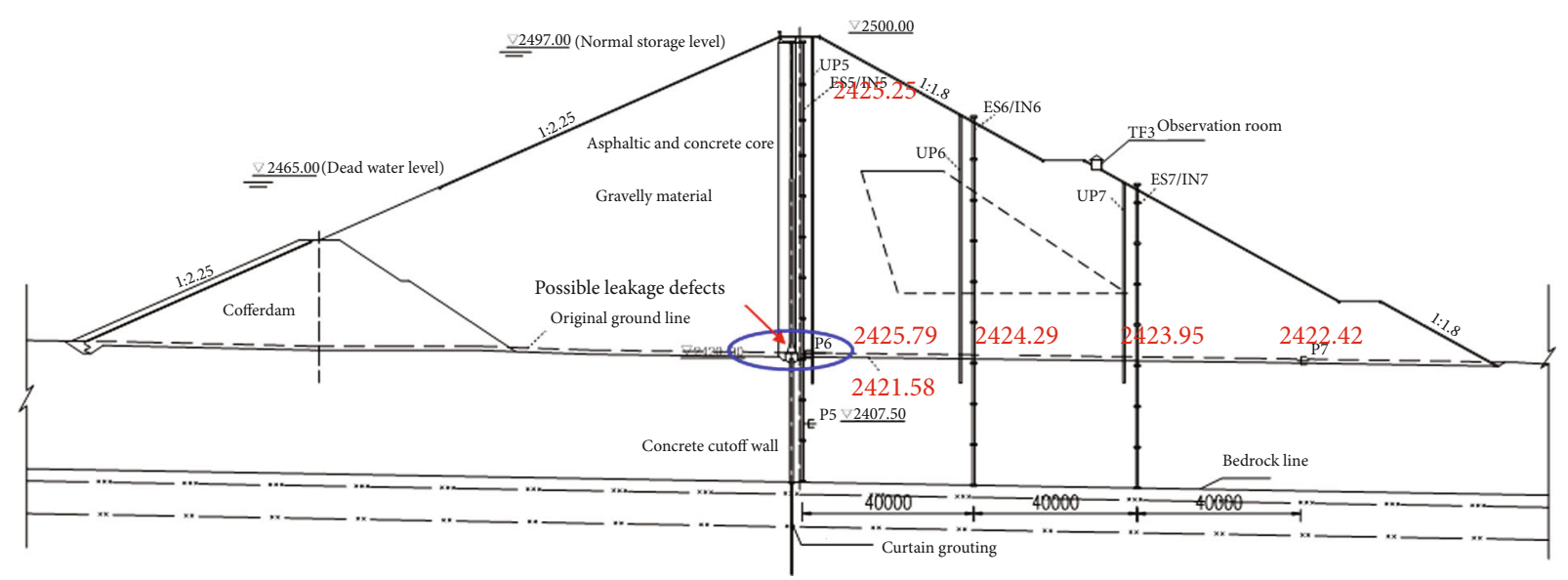

Figure 18: The distribution map of water level in the cross section $0+540$.

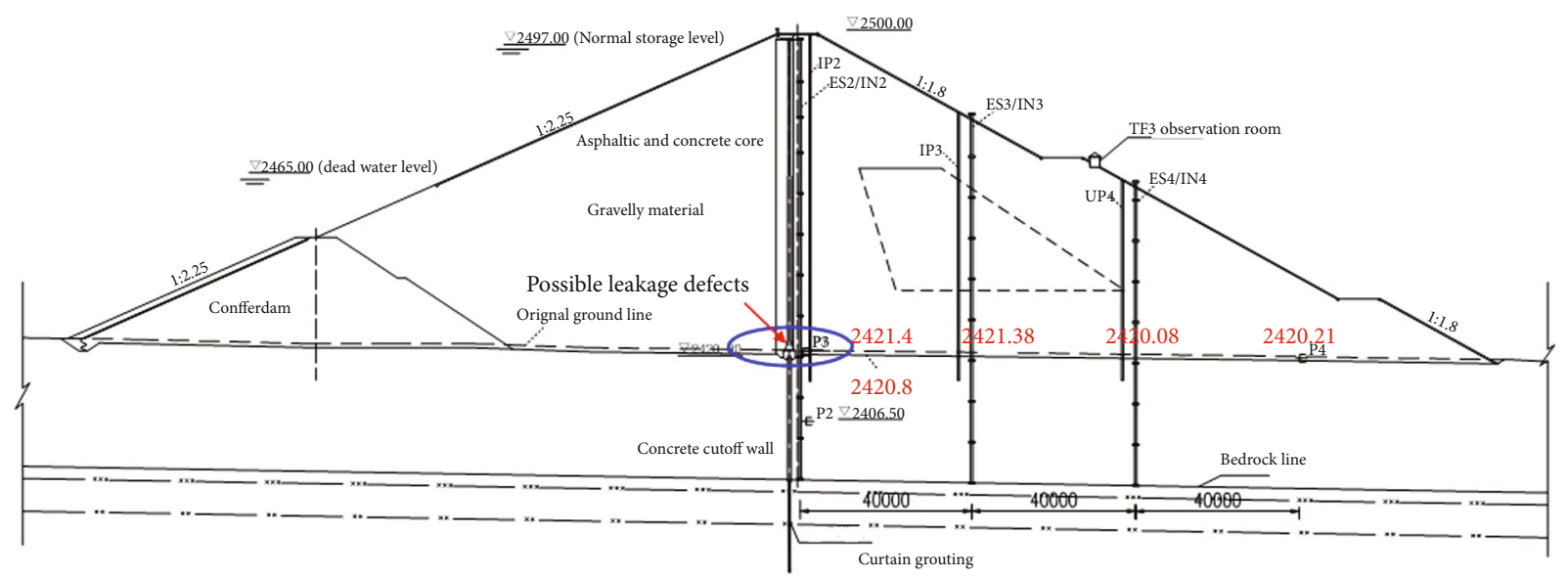

FIGURE 19: The distribution map of water level in the cross section $0+290$.

TABLE 2: The comparison of seepage pressure at monitoring points P2and P5.

\begin{tabular}{lccccc}
\hline $\begin{array}{l}\text { The number of monitoring } \\
\text { point }\end{array}$ & $\begin{array}{c}\text { Pile number } \\
(\mathrm{m})\end{array}$ & $\begin{array}{c}\text { The buried site } \\
\text { Distance from dam axis } \\
(\mathrm{m})\end{array}$ & $\begin{array}{c}\text { Elevation } \\
(\mathrm{m})\end{array}$ & $\begin{array}{c}\text { Monitoring } \\
\text { value }\end{array}$ & $\begin{array}{c}\text { The simulation } \\
\text { value }\end{array}$ \\
\hline P2 & $0+290$ & 0 & 2406.500 & 2420.704 & 2419.42 \\
P5 & $0+540$ & 0 & 2407.500 & 2421.307 & -1.28 \\
error
\end{tabular}

simulation. It is shown in Table 3 that the simulation values at monitoring points are lower than actual monitoring value, especially for the monitoring points P6 and P3; they are rather lower and, respectively, reduce $3.45 \mathrm{~m}$ and $5.65 \mathrm{~m}$, but the difference of magnitudes of other monitoring points is small; in total, the magnitudes of seepage pressure at the left and right banks are higher, and the ones in the middle pile number are lower; such a distribution law is represented in both methods. The conclusions can be drawn that certain leakage defects at the joint of an impermeable body at the cross sections $0+456.5 \mathrm{~m}$ and $0+540 \mathrm{~m}$ can exist by comparison.
(2) The Seepage Monitoring of the Downstream Dam Body. The monitoring value of seepage pressure at the cross sections $0+290 \mathrm{~m}$ and $0+540 \mathrm{~m}$ is, respectively, compared with the value of FEM simulation. It is shown in Table 4 that the simulation values are lower than the actual monitoring value; the magnitudes of seepage pressure at the cross section $0+290 \mathrm{~m}$ are reduced by $1.0 \mathrm{~m} \sim 2.0 \mathrm{~m}$; ones at the cross section $0+540 \mathrm{~m}$ are reduced by $4.0 \mathrm{~m} \sim 5.0 \mathrm{~m}$; a common issue is faced: the water levels of seepage pressure at the depth of the dam foundation at the downstream side of the cutoff wall are lower than the ones of foundation surface; this phenomenon does not confirm to the basic law of porous medium, so 
TABLE 3: The comparison of seepage pressure at the downstream of core base.

\begin{tabular}{|c|c|c|c|c|c|c|}
\hline $\begin{array}{l}\text { The number of monitoring } \\
\text { point }\end{array}$ & $\begin{array}{l}\text { Pile number } \\
(\mathrm{m})\end{array}$ & $\begin{array}{l}\text { The buried site } \\
\text { Distance from upstream wall } \\
(\mathrm{m})\end{array}$ & $\begin{array}{l}\text { Elevation } \\
(\mathrm{m})\end{array}$ & $\begin{array}{l}\text { Monitoring } \\
\text { value }\end{array}$ & $\begin{array}{l}\text { The simulation } \\
\text { value }\end{array}$ & $\begin{array}{l}\text { The } \\
\text { error }\end{array}$ \\
\hline $\mathrm{P} 1$ & $0+110$ & 0 & 2445.000 & 2446.061 & 2448.34 & 2.28 \\
\hline $\mathrm{P} 10$ & $0+166$ & 0 & 2420.800 & 2426.44 & 2428.70 & 2.26 \\
\hline P11 & $0+230.50$ & 0 & 2420.000 & 2422.766 & 2419.97 & -2.80 \\
\hline P3 & $0+290$ & 0 & 2420.000 & 2421.6 & 2419.22 & -2.38 \\
\hline $\mathrm{P} 12$ & $0+373.50$ & 0 & 2420.000 & 2420.978 & 2419.19 & -1.79 \\
\hline $\mathrm{P} 13$ & $0+456.5$ & 0 & 2420.000 & 2423.994 & 2420.54 & -3.45 \\
\hline P6 & $0+540$ & 0 & 2420.000 & 2425.773 & 2420.13 & -5.65 \\
\hline P14 & $0+620$ & 0 & 2425.000 & 2436.148 & 2434.46 & -1.69 \\
\hline P8 & $0+693$ & 0 & 2434.000 & 2442.729 & 24445.19 & 1.46 \\
\hline
\end{tabular}

TABLE 4: The comparison of seepage pressure at downstream dam body.

\begin{tabular}{|c|c|c|c|c|c|c|}
\hline $\begin{array}{l}\text { The number of monitoring } \\
\text { point }\end{array}$ & $\begin{array}{l}\text { Pile number } \\
(\mathrm{m})\end{array}$ & $\begin{array}{c}\text { The buried site } \\
\text { Distance from upstream wall } \\
(\mathrm{m})\end{array}$ & $\begin{array}{l}\text { Elevation } \\
(\mathrm{m})\end{array}$ & $\begin{array}{l}\text { Monitoring } \\
\text { value }\end{array}$ & $\begin{array}{l}\text { The simulation } \\
\text { value }\end{array}$ & $\begin{array}{l}\text { The } \\
\text { error }\end{array}$ \\
\hline $\mathrm{P} 2$ & $0+290$ & 0 & 2406.500 & 2420.704 & 2419.42 & -1.28 \\
\hline P3 & $0+290$ & 0 & 2420.000 & 2421.60 & 2419.22 & -2.38 \\
\hline UP2 & $0+290$ & 3 & 2419.899 & 2421.78 & 2419.15 & -2.62 \\
\hline UP3 & $0+290$ & 40 & 2417.144 & 2421.32 & 2418.89 & -2.43 \\
\hline UP4 & $0+290$ & 80 & 2414.000 & 2420.24 & 2418.73 & -1.51 \\
\hline P4 & $0+290$ & 120 & 2420.000 & 2420.42 & 2418.51 & -1.91 \\
\hline P5 & $0+540$ & 0 & 2407.500 & 2421.307 & 2420.17 & -1.13 \\
\hline P6 & $0+540$ & 0 & 2420.000 & 2425.773 & 2420.13 & -5.65 \\
\hline UP5 & $0+540$ & 3 & 2418.702 & 2425.35 & 2420.12 & -5.23 \\
\hline UP6 & $0+540$ & 40 & 2415.049 & 2424.42 & 2419.91 & -4.51 \\
\hline UP7 & $0+540$ & 80 & 2413.868 & 2424.21 & 2419.55 & -4.66 \\
\hline P7 & $0+540$ & 120 & 2420.000 & 2422.50 & 2418.98 & -3.52 \\
\hline
\end{tabular}

TABLE 5: The comparison of seepage pressure about dam-around seepage.

\begin{tabular}{lccccc}
\hline $\begin{array}{l}\text { The number of monitoring } \\
\text { point }\end{array}$ & $\begin{array}{c}\text { Pile number } \\
(\mathrm{m})\end{array}$ & $\begin{array}{c}\text { The buried site } \\
\text { Distance from upstream wall } \\
(\mathrm{m})\end{array}$ & $\begin{array}{c}\text { Elevation } \\
(\mathrm{m})\end{array}$ & $\begin{array}{c}\text { Monitoring } \\
\text { value }\end{array}$ & $\begin{array}{c}\text { The simulation } \\
\text { value }\end{array}$ \\
\hline UP9 & $0+9.027$ & 13.817 & 2415.427 & 2455.02 & 2452.08 \\
TP10 & $0+98.624$ & 71.274 & 2421.455 & 2437.06 & 2431.06 \\
error
\end{tabular}

conclusions can be drawn that there exists a leakage defect at the joint of an impermeable body at $2420 \mathrm{~m}$.

4.3.3. The Comparison of the Dam-Around Seepage Monitoring. The monitoring value of the dam-around seep- age at the left and right banks is compared with the value of FEM simulation. It is shown in Table 5 that the monitoring values of monitoring points UP10 and UP11 at the left bank are, respectively, higher $(6.0 \mathrm{~m}$ and $7.24 \mathrm{~m})$ than simulation value, because their distance from the axis line is far; the 
extravasation of water in the spillway tunnel results from the higher monitoring value. The monitoring value at the right bank is very close to the simulation value; the difference is less than $2 \mathrm{~m}$. These demonstrate that the hydrogeological condition conforms to the actual conditions.

\section{Conclusions}

(1) When the antiseepage system of the dam foundation is good, the water level on the downstream side in the dam body is greatly reduced

(2) The seepage field of the dam body and foundation from FEM simulation is basically consistent with the monitoring results; the water level of seepage pressure is basically lower than the monitoring water level, especially for the cross sections $0+456.5 \mathrm{~m}$ and $0+540 \mathrm{~m}$; their reduced magnitude is more, so the conclusions can be drawn that certain leakage defects at the joint of an impermeable body at the cross sections $0+456.5 \mathrm{~m}$ and $0+540 \mathrm{~m}$ can exist

(3) The seepage pressure of bottom monitoring points is lower than one of the dam foundation at the cross sections $0+290 \mathrm{~m}$ and $0+540 \mathrm{~m}$ in the dam section; it can be concluded that there exists a leakage defect at the joint of an impermeable body at the height $2420 \mathrm{~m}$

(4) The calculation and analysis of the dam-around seepage at the left and right banks demonstrate that magnitudes of monitoring points UP10 and UP11 at the left bank are higher; the extravasation of water in the spillway tunnel can be a direct factor; the monitoring value at the right bank is very close to the simulation value; these demonstrate that the hydrogeological condition conforms to the actual conditions of projection

\section{Data Availability}

The data used to support the findings of this study are available from the corresponding author upon request.

\section{Conflicts of Interest}

The authors declare that they have no conflicts of interest.

\section{Acknowledgments}

This work is supported by the first batch of Natural Science Foundation of Sichuan Provincial Department of Education (no. 17ZA0270), the cross project in Nanyang Institute of Technology (230067), and the general scientific research project of Zhejiang Provincial Department of Education (Y201839661).

\section{References}

[1] Q. Q. Guo, Z. Han, S. H. Zhang, and Y. Li, "Comprehensive analysis on seepage and structural stability of earth-rock dam: a case study of Xiquanyan Dam in China," Civil Engineering Journal, vol. 25, no. 2, 2016.

[2] W. Zhou, J. Hua, X. Chang, and C. Zhou, "Settlement analysis of the Shuibuya concrete-face rockfill dam," Computers and Geotechnics, vol. 38, no. 2, pp. 269-280, 2011.

[3] H. Su, Y. Kang, and S. Huaizhi, "Design of system for monitoring seepage of levee engineering based on distributed optical fiber sensing technology," International Journal of Distributed Sensor Networks, vol. 9, no. 12, Article ID 358784, 2013.

[4] L. Ding, Q. Qian, J. Zhao, and J. Wu, “A comparative study on the processing methods of multicollinearity in dam monitoring data," Urban Geotechnical Investigation \& Surveying (in Chinese), vol. 6, pp. 139-142, 2017.

[5] K. Rafifiezadeh and B. Ataie-Ashtiani, "Transient free-surface seepage in three-dimensional general anisotropic media by BEM," Engineering Analysis with Boundary Elements, vol. 46, no. 46, pp. 51-66, 2014.

[6] L. Gan, X. Z. Shen, and W. Qing, "Seepage analysis of concrete face rockfill dam for material damage of water stop structure," Key Engineering Materials, vol. 729, pp. 93-98, 2017.

[7] A. Larese, R. Rossi, and E. Oñate, "Finite element modeling of free surface flow in variable porosity media," Archives of Computational Methods in Engineering, vol. 22, no. 4, 2015.

[8] B. Xu, D. G. Zou, and H. B. Liu, "Three-dimensional simulation of the construction process of the Zipingpu concrete face rockfill dam based on a generalized plasticity model," Computers and Geotechnics, vol. 43, no. 6, pp. 143-154, 2012.

[9] Y. Xiang, L. Wang, S. S. Wu, H. Yuan, and Z. J. Wang, "Seepage analysis of the fractured rock mass in the foundation of the main dam of the Xiaolangdi water control project," Environmental Earth Sciences, vol. 74, no. 5, pp. 4453-4468, 2015.

[10] S. K. Chen and X. Zhang, "Seepage control in a high concrete face-rock fill dam based on the node virtual flow method," The Open Construction \& Building Technology Journal, vol. 10, no. 1, pp. 547-560, 2016.

[11] X. H. Tan, X. Wang, S. Khoshnevisan, X. L. Hou, and F. Zha, "Seepage analysis of earth dams considering spatial variability of hydraulic parameters," Engineering Geology, vol. 228, pp. 260-269, 2017.

[12] Y. W. Choo, D. H. Shin, S. E. Cho, E. S. Im, and D. Kim, "Seepage behavior of drainage zoning in a concrete faced gravel-fill dam via centrifuge and numerical modeling," KSCE Journal of Civil Engineering, vol. 17, no. 5, pp. 949-958, 2013.

[13] J. Ren, Z. Z. Shen, J. Yang, and C. Z. Yu, "Back analysis of the 3D seepage problem and its engineering applications," Environmental Earth Sciences, vol. 75, no. 2, 2016.

[14] S. Liu, Q. Zhao, M. Wen, L. Deng, S. Dong, and C. Wang, "Assessing the impact of hydroelectric project construction on the ecological integrity of the Nuozhadu Nature Reserve, Southwest China," Stochastic Environmental Research and Risk Assessment, vol. 27, no. 7, pp. 1709-1718, 2013.

[15] J. Bi, X. P. Zhou, and Q. H. Qian, "The 3D numerical simulation for the propagation process of multiple pre-existing flaws in rock-like materials subjected to biaxial compressive loads," Rock Mechanics and Rock Engineering, vol. 49, no. 5, pp. 1611-1627, 2016.

[16] J. Zhang, J. Wang, and H. Cui, "Causes of the abnormal seepage field in a dam with asphaltic concrete core," Journal of Earth Science, vol. 27, no. 1, pp. 74-82, 2016.

[17] Y. F. Chen, R. Hu, W. B. Lu, D. Q. Li, and C. B. Zhou, "Modeling coupled processes of non-steady seepage flow and non- 
linear deformation for a concrete-faced rockfill dam," Computers \& Structures, vol. 89, no. 13-14, pp. 1333-1351, 2011.

[18] Z. Xiao-Ping, X. En-Ming, H.-Q. Yang, and Q. Qi-Hu, "Different crack sizes analyzed for surrounding rock mass around underground caverns in Jinping I hydropower station," Theoretical and Applied Fracture Mechanics, vol. 57, no. 1, pp. 1930, 2012.

[19] L. F. Shao and Y. Y. Xin, "Safety evaluation of earth-rock dam based on projection pursuit analysis and normal cloud model," Water Resources and Power, vol. 33, no. 12, pp. 81-84, 2015.

[20] Z. Tan, Q. Zou, and W. Liu, "Innovation and practice on monitoring design of Nuozhadu high core rockfill dam," Water Power, vol. 38, no. 9, pp. 90-92, 2012.

[21] T. Fang, Z. Y. Zhang, and X. Wen-Bin, "Analysis of seepage monitoring model for earth-rock dams," Journal of Heilongjiang Hydraulic Engineering College (in Chinese), vol. 34, pp. 28-30, 2007.

[22] F. U. Meng, H. Chen, and H. U. Kun, "Monitoring of surrounding rock deformation and support stress during excavation of Nouzadu underground power house," Yangtze River, vol. 43, pp. 80-84, 2012.

[23] H. Cheng, X. Zhou, X. Pan, and F. Berto, "Damage analysis of sandstone during the creep stage under the different levels of uniaxial stress using NMR measurements," Fatigue \& Fracture of Engineering Materials \& Structures, vol. 44, no. 3, pp. 719$732,2021$.

[24] J. Chen, Y. Shou, and X. Zhou, "Implementation of the novel perfectly matched layer element for elastodynamic problems in time-domain finite element method," Soil Dynamics and Earthquake Engineering, vol. 152, article 107054, 2022.

[25] X. P. Zhou, X. Pan, and H. Cheng, "The nonlinear creep behaviors of sandstone under the different confining pressures based on NMR technology," Rock Mechanics and Rock Engineering, vol. 54, no. 9, pp. 4889-4904, 2021. 